\title{
Left Ventricular Outflow Tract Peak Velocity
}

National Cancer Institute

\section{Source}

National Cancer Institute. Left Ventricular Outflow Tract Peak Velocity. NCI Thesaurus. Code C127568.

The measurement of the maximum rate of blood flow measured in the left ventricular outflow tract during systole. 